\title{
The British Species of Trivia: T. arctica and T. monacha.
}

\author{
By \\ Marie V. Lebour, D.Sc., \\ Naturalist at the Plymouth Laboratory.
}

With one Plate.

THE two forms of Trivia which are recorded from Plymouth (Marine Biological Association, 1931) have hitherto been regarded as one species (Trivia europea), but recent researches (Peile, 1925; Pelseneer, 1932) have shown them to be distinct. Peile calls the two species Trivia monacha (Da Costa), with the spotted shell, and Trivia arctica (Montagu), with the unspotted shell. Pelseneer calls them respectively Cyprcea (Trivia) europcea L. and Cyprcea (Trivia) arctica Montagu. A closer investigation at Plymouth fully bears out the conclusion of the above-mentioned workers that there are two species and the fact, brought forward for the first time in the present paper, that the larvæ are also distinct makes the determination doubly sure.

Winckworth (1932) in his latest list of British marine mollusca retains the two as one species, Trivia monacha (Da Costa), distinguishing them as Trivia monacha monacha (Da Costa) and Trivia monacha arctica (Montagu). In view of these recent researches they must be regarded however as two distinct species, and we here follow Peile in calling them Trivia monacha (Da Costa) and Trivia arctica (Montagu). The name Trivia europaca, unfortunately, must be allowed to lapse. The two forms were recognised by Linnaeus who called them Cypraea europcea and $C$. anglica, but it is agreed by most systematists that these terms were only given in a geographical sense and cannot be accepted as names.

In Plymouth a smaller, lighter coloured form from deeper water has been distinguished from a coastal form which is darker, more brightly coloured, and usually larger. This difference does not altogether differentiate the two species. The smaller, lighter form from deeper water is certainly Trivia arctica, but the coastal animals belong both to this species and to Trivia monacha. The two may be separated immediately by the shells, Trivia monacha having brown spots on the dorsal surface, always arranged in the same way, one anterior, one posterior, and two in the centre situated obliquely one on each side of the central line and merging 
into one, Trivia arctica having no spots, or, very rarely, the merest trace of brown; generally speaking the spots being totally absent. In Trivia monacha they are only absent in the young forms, being formed, as Pelseneer (1932) has shown, when the transverse ribs are acquired.

The colouring of the animal of Trivia arctica from between tide-marks and dredged in shallow water (the Sound) may be very like that of Trivia monacha with dark spots and stripes, and they are usually larger than those from deeper water. Trivia monacha is never found in the deeper water although it may be dredged occasionally from the Sound and just outside. In the young animals before the shell is thickened the body is often very light-coloured.

The usual habitat of Trivia monacha, often with Trivia arctica, at Plymouth is under rocks and rock ledges among compound ascidians (Botryllus, Botrylloides, and Diplosoma) between tide-marks and at extreme low tide. The specimens of $T$. arctica from deeper water are dredged with ascidians and bryozoa.

The natural food of both species appears to be compound ascidians for both species devour these animals in captivity, especially Diplosoma listerianum (Milne Edwards) var. gelatinosum (Milne Edwards) which is common growing on the glass sides of the Laboratory tanks and which if detached and placed in the plunger-jars will grow there comfortably. They will also eat Botryllus, Botrylloides, and Trididemnum. Pelseneer (1926) finds that on the Brittany coast they eat Polyclinum luteum. Vayssière (1923) found in the stomachs of Trivia (called by him Trivia europaca and probably a mixture of both species) from the Gulf of Marseilles the debris of algæ mixed with foraminifera and other microscopic animalcules, but from the way they devour the compound ascidians it seems that this is the more natural food, the smaller organisms probably being taken in accidentally. The compound ascidians from the shallow water are often much darker than those from the deeper water, which fact may account for the persistent difference in the colour of Trivia arctica from shallow and deep water.

An interesting point in the colouring of Trivia arctica is that the mantle shows brown spots, more or less distinct, in the position in which they are present on the shell of Trivia monacha although in Trivia arctica there are no spots on the shell.

The general account of Trivia europaca by Vayssière (op. cit.), giving Trivia arctica as a synonym, embraces both species, but those he specially dissected and figured are from fairly deep water $(50-80 \mathrm{~m}$.) in the Gulf of Marseilles and are certainly Trivia arctica, having the characteristic unspotted shell, distinctive radulæ and penis of that species. Both species thus occur in the Mediterranean.

The two species are evidently closely related, but Trivia arctica has a 
more northerly distribution than Trivia monacha. The breeding season fits in with this fact. At Plymouth Trivia arctica breeds through the autumn and winter, dwindling in late spring, whilst Trivia monacha begins to breed in spring when Trivia arctica leaves off, and continues through the summer, the larva very rarely being seen in autumn:

Trivia arctica is the only species in Scandinavia extending through Britain to the Mediterranean. Trivia monacha begins in Britain and is common in the Mediterranean and along the western coast of France. It is difficult to quote records with certainty as the two species have been mixed together and regarded as one for so long. Pelseneer $(1926,1932)$ found both species together on the Brittany coast.

The species may be distinguished in the animal by the radula, the shape of the penis and by the larvæ. Of these characters the shape of the penis is perhaps the most important. The female opening corresponds in size and cross fertilisation between the species is impossible. Pelseneer (1926) first discovered this character in the two species from the Brittany coast and emphasises it in his second paper (1932). He finds that Trivia arctica possesses a large and flat penis, somewhat leaf-like, and in Trivia monacha it is filiform and cylindrical.* These differences I can confirm from the Plymouth specimens.

Peile (op. cit.) described the difference in the radulæ, this being confirmed by Pelseneer (1932), and I have found the difference absolutely constant. In Trivia arctica there are small denticles on the admedian teeth, in Trivia monacha there are none. Peile also found the number of rows of teeth was different in the two species, Trivia arctica having less than Trivia monacha. He also mentions an observation made by Mr. Wintle that " in the unspotted form the riblets pass quite evenly across the shell, those of the spotted form are less uniform, frequently bifurcate and sometimes anastomose." On looking into these two last-mentioned characters I have found that the number of rows of teeth is extremely variable and that the riblets very often anastomose in $T$. arctica as well as in $T$. monacha. These characters are therefore not reliable.

The mantle of Trivia is provided with a number of papillæ. These are more numerous in the young of both species, but in the adult there are many more of them in Trivia arctica. The number varies, but sometimes this species appears to be bristling with them like a hedge-hog.

Pelseneer (1926) first discovered the eggs of Trivia europaca (undifferentiated) embedded in the compound ascidian Polyclinum luteum on the Brittany coast, and hatched some of them out. He also describes and figures the eggs and newly hatched larvæ. As these were found in the

\footnotetext{
* By some slip these characters are reversed in Pelseneer's first paper. The filiform penis being attributed to Trivia arctica and the flat one to Trivia monacha. This is righted in the second paper.
} 
PLATE 1.
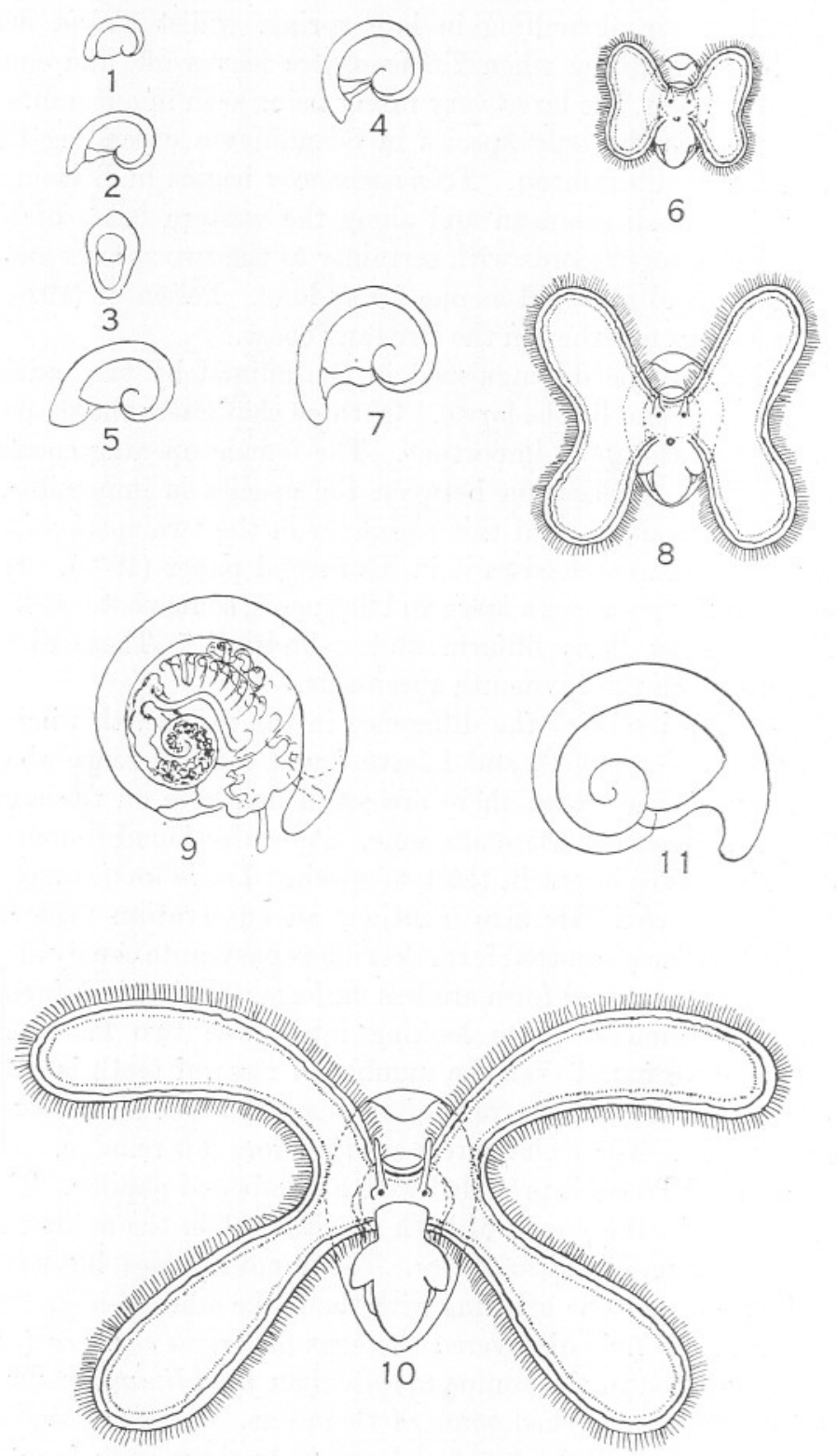
summer they are almost certainly the eggs of Trivia monacha. In June, 1931, I succeeded in obtaining some eggs from Trivia monacha laid in compound ascidians (Botryllus and Diplosoma) in a plunger-jar, and hatched some of them out, obtaining similar larvæ and later stages from the plankton, the later stages being kept until they metamorphosed. In the same year I published a paper on the eggs and larvæ of Trivia europcea (Lebour, 1931a), regarding both forms as one. It is now certain, however, that the description applied to Trivia monacha, the only exceptions being probably the autumn and winter records of the larvæ which are almost certainly Trivia arctica, for it is now found that Trivia monacha breeds almost exclusively in late spring and summer.

The eggs of Trivia arctica have not been found, the adults kept in the Laboratory refusing to lay although given every facility and provided with various ascidians. It is to be expected, however, that the eggs will be very like those of Trivia monacha. In autumn and winter to late spring, very rarely in early summer, a larva was seen in the plankton which, although in the very young stages was exactly the shape of that belonging to Trivia monacha, differed constantly in the colouring of the animal, the intestines being yellowish with only a very little darkish pigment at the sides of the stomach (Plate 1, Figs. 1-9). In Trivia monacha the animal is consistently dark, from the stomach and intestine being almost black, the digestive gland also being very dark. In all stages this difference is conspicuous. At first the animal is much the same in form in both species, the accessory shell and the true shell being exactly similar (Plate 1, Figs. $1-7)$, but as the larva grows a distinct difference is seen in the velum. At first the lobes of the velum are oval (Plate 1, Fig. 6) and then slightly indented at the sides (Plate 1, Fig. 8). Soon, however, the indentation becomes larger in Trivia arctica (whilst it remains only slight until the last in Trivia monacha) and finally in the late larvæ the four lobes are long, much longer than the shell (Plate 1, Fig. 10). In both species the velum

EXPLANATION OF PLATE 1.

Trivia arctica from plankton.

(All drawn to the same scale.)

FIG. 1.-Very young larva, $0 \cdot 40 \mathrm{~mm}$. across.

Frgs. 2-4.-Slightly older larvæ, 0.48-0.60 mm. across.

Fig. 5.-Larva $0.64 \mathrm{~mm}$. across.

FIG. 6.-The same, with velum expanded.

Fig. $\quad$ 7.-Older larva, $0.96 \mathrm{~mm}$. across.

FIG. 8.- The same, with velum expanded.

FIG. 9.-Larva ready to metamorphose, $1.60 \mathrm{~mm}$. across.

FIG. 10.-The same, with velum expanded.

FIG. 11.-Late larval shell, without animal. 
is bordered by a fine line of dark brown. The shell is rather larger in Trivia arctica when metamorphosis takes place and may be $1.6 \mathrm{~mm}$. across (Plate 1, Figs. 9-11), usually 1.25 mm. in Trivia europxa. When swimming the difference in the colouring of these late larvæ can be seen with the naked eye.

These late larvæ of Trivia arctica from the plankton were placed in a plunger-jar with Nitzschia and they soon metamorphosed just in the same way as is described for Trivia monacha (Lebour, op. cit., 1931a, as T. europ $x a$ ), the mantle growing round the accessory shell. Diplosoma was growing on the glass slides of the jar and the little metamorphosed animals began to eat this and very soon grew up. The colouring of these adolescent animals was in all cases yellowish with minute blackish purple spots, never orange or bright yellow as is often the case in Trivia monacha, and the spots not congregated in definite masses as in that species until much later. Later, when the stripes on the mantle begin to appear (as is described by Pelseneer (1932) for Trivia monacha), the spots are grouped dorsally more or less distinctly into three masses, one anterior, one posterior, and two in the centre merging into one, these masses corresponding to the positions of the spots in Trivia monacha. Minute dark spots are also scattered round the base of the siphon and irregularly on the body and also on the papillæ which are usually tipped with pale yellow. There are also sometimes pale yellow flecks on the siphon and tentacles. In three months the elongated shell was well formed although still thin. In four or five months the ridges were beginning to form preceded by the dark lines in the mantle. In five or six months the adult form was reached. The whole process of thickening takes place exactly as Pelseneer describes it in Trivia monacha (1932). At five months the distinctive denticles show on the admedians of the radula. There are now (September 1932) in the plunger-jar six fully-grown specimens of Trivia arctica reared from the late larvæ from the plankton. At six months these were fully grown and measured from 8 to $9 \mathrm{~mm}$. in length. These vary in age from 6 to 8 months. All have a yellowish foot and mantle with fine dark spots as described above, pale yellowish spots on the tentacles, siphon, and papillæ, and many papillæ on the mantle. They have been reared on Diplosoma which they still continue to eat. Pelseneer (1932) gives the length of adult Trivia monacha as from 8.35 to $15.4 \mathrm{~mm}$., these being the two extremes. Usually not less than $10 \mathrm{~mm}$. Vayssière gives 6 to $12 \mathrm{~mm}$. for the Marseilles specimens (almost certainly Trivia arctica). In Plymouth the deeper-water Trivia arctica measure usually from 8 to $10 \mathrm{~mm}$. in length when adult, those from the coastal waters being larger, up to about $12 \mathrm{~mm}$., Trivia monacha from the same locality being about 10 to $13 \mathrm{~mm}$.

The larvæ of Trivia monacha were not so successfully reared although 
they metamorphosed in captivity. Those which grew beyond the round form had a bright orange mantle and the dark spots more apparent, but specimens of the same size from the Sound were sometimes lighter in colour although having the same arrangement of dark spots congregated in masses as is figured by Pelseneer (1932) and by myself (1931a). At a length of $3.5 \mathrm{~mm}$. these are quite distinct and characteristic, and it is perfectly easy to distinguish the adolescent form before the thickening of the lip and the formation of the spots on the shell (in Trivia monacha).

Both species are common at Plymouth, sometimes at low tide they may be found together in equal numbers, sometimes only one species in one place. For instance, at Whitsand Bay in July, Mr. William Searle collected from the rocks at low tide 28 specimens of Trivia monacha but no Trivia arctica. In Wembury Bay, Rum Bay, and Drake's Island both species may be collected in fair numbers. In the Sound adult species of both may be dredged, but Trivia monacha is only very rarely dredged outside, whilst Trivia arctica is common in small numbers from the Mewstone and Eddystone grounds and even sometimes farther out. In the plankton the larvæ of Trivia arctica occur commonly in autumn, winter, and early spring, the early larva chiefly in autumn and winter, the late larva in spring until about the end of May, both inside and outside the Sound. From May all through the summer, dwindling in October and practically absent from November to April, the larvæ of Trivia monacha are common, chiefly from inside or just outside the Sound, only very occasionally farther out.

The two species are thus distinguishable both in the larval stages and in the adult by colour, Trivia monacha always having more pigment which extends to the shell. The adults may be separated by the following characters :-

\section{Trivia monacha.}

More southerly distribution. Breeding season late spring and summer.

Shell spotted, usually larger than T. arctica.

Mantle dark, foot orange or bright yellow, lighter in young forms.

Mantle with few papillæ.

Radula without denticles on the admedian teeth.

Penis cylindrical and thin.

\section{Trivia arctica.}

More northerly distribution. Breeding season autumn, winter, and early spring.

Shell unspotted, usually smaller, but sometimes on the coast as large as $T$. monacha.

Mantle light in deeper water, darker between tide-marks, foot light yellow or light orange.

Mantle with many papillæ.

Radula with denticles on the admedian teeth.

Penis leaf-like and broad. 


\section{Trivia monacha.}

Larva with very dark stomach and intestine.

Late larva with two-lobed velum only slightly indented at sides. Metamorphosing at about $1.25 \mathrm{~mm}$.

\section{Trivia arctica.}

Larva with light stomach and intestine.

Late larva with four-lobed velum, very long lobes. Metamorphosing at about $1.44 \mathrm{~mm}$.

It is interesting to find again two closely related species of one genus having distinct larvæ corresponding to the distribution, as is the case with the two species of Nassarius, N. reticulatus and $N$. incrassatus (see Lebour, 1931b). In both cases the two species may live together between tidemarks but one may be found also in deeper water. In the case of the deeper-water species, the larva has very long lobes to the velum corresponding to its wider distribution and indicating one which can live longer in a planktonic state. Here we have the shore-living Trivia monacha and Nassarius reticulatus having the velum with two lobes only slightly indented and although they can live a long time in the plankton it is probable that Trivia arctica and Nassarius incrassatus, which are able to live in deeper water, with the long velar lobes are stronger and are adapted to being carried further.

\section{LITERATURE.}

Lebour, M. V. 1931a. The Larval Stages of Trivia europea. Journ. Mar. Biol. Assoc., N.S., Vol. XVII, No. 3, pp. 819-832.

1931b. The Larval Stages of Nassarius reticulatus and Nassarius incrassatus. Ibid., pp. 797-818.

Marine Biological Association. Plymouth Marine Fauna, 1931, pp. 1-370.

Peile, A. J. 1925. The Differentiation as Species of the two Forms of British Trivia. Proc. Malac. Soc., 1925, pp. 195-198.

Pelseneer, P. 1926. Note d'Embryologie Malacologique. Ponte et développement de Cyprca europea, etc. Bull. Biol. de la France et de la Belgique, LX, I, pp. 88-112.

1932. La Métamorphose préadulte des Cypræidæ. Ibid., LXVI, 2, pp. 149-163.

VAyssière, A. 1923. Recherches Zoologiques et anatomiques sur les mollusques de la Famille des Cypræidés. I ${ }^{\text {re }}$ Partie. Ann. Mus. d'Hist. Nat. de Marseille Zoologie. T. XVIII, pp. 1-120.

Winckworth, R. 1932. The British Marine Mollusca. Journ. of Conchology, Vol. 19, No. 7. June. 